Welcome in! How the academy can warrant recognition of young children as researchers Jane Murray

The Centre for Education and Research, The Faculty of Education and Humanities, The University of Northampton, Northampton, UK 


\title{
Welcome in! How the academy can warrant recognition of young children as researchers Jane Murray
}

The Centre for Education and Research, The Faculty of Education and Humanities, The University of Northampton, Northampton, UK

\begin{abstract}
The academy has tended to marginalise young children as researchers, even in matters affecting them, which denies young children agency and amounts to social injustice. Drawing on the Young Children As Researchers (YCAR) study, which adopted a qualitative 'jigsaw' methodology to co-research with children aged 4-8 years $(n=138)$, their parents, practitioners, and professional researchers, this article considers epistemological factors and epistemological categories that may support young children's research behaviours in everyday activities. Those support structures are helpful in securing a warrant for recognising young children's selfdirected research on the academy's terms. That recognition has potential to reposition young children away from the margins of research to an intrinsic position in research concerning matters that affect them, securing their rights as researchers. Such research can inform early childhood policy and practice in a deeply grounded manner that values young children as competent thinkers with expertise concerning their own lives.
\end{abstract}

\section{Keywords}

Young Children as Researchers, early childhood education, epistemological factors, epistemological categories, jigsaw methodology, marginalisation.

\section{Introduction}

Engagement in research is a right (Appadurai, 2006) that has been afforded to adults, older children and young people who conform to the academy's constructions of research (Alderson, 2001; Brownlie, Anderson and Ormston, 2006; Fielding, 2001; Kellett, 2005). The academy has not appeared equally ready to recognise younger children as researchers, so that those in early childhood - 0-8 years - (OHCHR, 2005) have remained marginalised from the academy's privileged 
research spaces, even in matters affecting them (Redmond, 2008; OHCHR, 1989). From the perspective that children are 'experts in their own lives' (Langsted 1994: 29), this situation denies younger children agency, amounting to social injustice. Drawing on the Young Children As Researchers (YCAR) study (Murray, 2012; 2013; 2014; 2015ab; 2016; 2017), this article presents previously unpublished material exemplifying ways that specific support structures can provide warrant for young children's everyday activities to be recognised as research behaviours that congruence with the research behaviours of professional adult researchers. Such a warrant underpins justification for young children's rights to research to be respected and upheld on equal terms with those of professional adult researchers, particularly concerning matters affecting young children.

\section{Young Children As Researchers (YCAR) study}

The YCAR aim was to conceptualise ways that young children aged 4-8 years are researchers, could develop as researchers and may be considered researchers. There were four research questions:

- What might research be like in early childhood education and care?

- How can a study be conducted to establish young children as researchers?

- What enquiries are important to young children and how can they engage in them?

- What support structures might encourage young children to participate in research? What barriers might prevent this?

This article focuses on the first part of the final research question: support structures for young children's participation in research and particularly how these can provide a warrant for the academy to recognise young children as researchers.

\section{Five Starting Points for the YCAR Study}

YCAR emerged from five starting points concerned with challenges and possibilities in recognising young children as researchers. (i) Firstly, in England where the study was conducted, young 
children's opportunities to make decisions about their own learning have decreased, while education policy has focusing increasingly on academic attainment measured against extrinsically specified outcomes. (ii) Secondly, in westernised contexts, young children tend to be excluded from the academy, defined as a space where knowledge is produced and 'learners and knowledge producers' converge, yet also a 'rarefied', hegemonic 'score-keeping world' which sets itself apart and makes powerful judgements concerning how knowledge is valued as research and the processes that produce it (Bridges, 1998; Lees, 1999:382; Redmond, 2008:9; Warren and Boxall, 2009:281). (iii) Third, when children are marginalised from research about matters affecting them they are denied rights to express their views and 'impart information and ideas' (OHCHR, 1989). Much research concerning children's perspectives tends to be conducted on or about children, rather than with or by children (Woodhead and Faulkner, 2008). (iv) Fourth, young children are viewed as competent, capable rights holders (James and James, 2008; OHCHR, 1989; Sen, 1993) and 'sophisticated' thinkers able to 'participate in the creation of themselves and their knowledge' (Dahlberg and Lenz Taguchi, 1994:2; Papert, 1980:132). (v) Finally, in recent years, there has been limited recognition that children can be researchers; whilst there is some precedent for recognising children younger than 8 years as co-researchers (Clark and Moss, 2011), it is far more common in respect of older children and young people. Yet whatever their age, when children and young people are positioned as co-researchers, the focus tends to be on training them in the academy's research protocols (Fielding, 2001; Kellett, 2005; O'Kane, 2008). Recognition of young children's self-chosen, selfdirected everyday activities as research remains rare: Piaget described young children as 'little scientists' (Fernyhough, 2010:158) and Hedges' work on young children's working theories suggests that when children test and explore ideas, they build knowledge (2014: 37). Equally, Cagliari et al. (2016) suggest that the Reggio Emilia approach regards children as 'innate carriers of what we could call an "epistemological curiosity" for researching into meanings' (p.307), while Isaacs (1944) observed that the 'factor of epistemic interest and inquiry...is in every respect the same in the child as in the adult' (p.322). 
Recognising meanings and thoughts inherent in children's behaviours may be challenging for adults; children '...have an autonomous world, independent to some extent of the worlds of adults' and their behaviours, meanings and thoughts can be 'incomprehensible to adults' (Hardman, 1973:95). Equally, young children tend to present their actions, meanings and thinking through '...play, body language, facial expression, or drawing and painting' (Lansdown, 2010:12): ways that do not easily conform to the academy's favoured means of working.

YCAR captured examples of young children's 'epistemic interest and inquiry' in their everyday activity (Isaacs, 1944) and revealed their congruence with professional adult researchers' behaviours, to establish a warrant for recognising young children as researchers on the academy's terms, particularly in matters affecting them.

\section{Research Design}

To secure that warrant, YCAR had to be constructed in a way that the academy would value. Whilst methodological conventions that are well-rehearsed within the academy were adopted, they included participatory, democratic approaches that addressed the YCAR study's focus on social justice (Freire, 1972; O'Kane, 2008; OHCHR, 2005). The research design allowed for empirical data to be co-constructed with participants (Charmaz, 2006), foregrounding children aged 4-8 years.

A single paradigm was rejected in favour of carefully selected plural paradigms; these included constructivism so that individual participants' views were regarded as truths that built knowledge (Ackerman, 2001), interpretivism which valued participants' subjective realities (Hughes, 2010), and critical research to reify transformation (Hatch, 2007). The plural paradigm model was mirrored by a 'jigsaw methodology', a qualitative pluralist approach (Frost et al., 2010; Murray, 2016; 2017) which was shaped in response to participants' views as the study progressed. The jigsaw methodology 
comprised four methodologies, each playing a key role, whilst complementing the other methodologies. Constructivist grounded theory enabled data to be constructed from participants' views, actions and interactions (Charmaz, 2006). Critical ethnography focused on social justice and transformation (Carspecken, 1996), the mosaic approach enabled co-construction of data with participants, including children (Clark and Moss, 2011), while descriptive case study facilitated the organisation of data collection and analysis across multiple sites (Yin, 2012).

Participants were professional adult researchers from the fields of education and early childhood, children aged 4-8 years, their parents and practitioners. They engage in collaborative processes of data collection, analysis and meta-analysis. YCAR was co-constructed in three phases (Table 1).

Phase 1 identified how professional adult researchers defined 'research', for later comparison with data captured in Phases 2 and 3. Phase 1 was important because participating professional adult researchers were academy members, and therefore powerful in the research space (Bridges, 1998; Lees, 1999; Redmond, 2008; Warren and Boxall, 2009).

Table 1: Three Phases, their Participants and Methods

\begin{tabular}{|c|c|c|c|}
\hline Phase & Participants & $\mathrm{N}=$ & Methods \\
\hline 1 & $\begin{array}{l}\text { Professional Educational and Early Years } \\
\text { Researchers }\end{array}$ & $\begin{array}{l}\mathrm{N}=34 \text { Professional } \\
\text { Educational and } \\
\text { Early Years } \\
\text { Researchers }\end{array}$ & $\begin{array}{c}\text { Survey } \\
\text { Semi-structured interviews } \\
\text { Focus group } \\
\text { Nominal grouping exercise }\end{array}$ \\
\hline \multirow[t]{4}{*}{2} & $\begin{array}{l}\text { Self-selected settings in suburban primary } \\
\text { schools judged ' } 2=\text { Good' by national regulator } \\
\text { Ofsted, on a scale of } 1-4 .\end{array}$ & \multirow{4}{*}{$\mathrm{N}=15$ practitioners } & \multirow{4}{*}{$\begin{array}{c}\text { Field notes } \\
\text { Interview conversations } \\
\text { Observations } \\
\text { Focus Groups } \\
\text { Informal discussions } \\
\text { Documents } \\
\text { Children's artefacts } \\
\text { Photographs } \\
\text { Video recordings } \\
\text { Audio recordings } \\
\text { RBF analysis sheets }\end{array}$} \\
\hline & $\begin{array}{l}\text { Ash Setting: } 7-8 \text { year-old boys and girls }(n=32) \\
\text { and their practitioners } \\
(n=3) \text {. Teacher-directed, programmed } \\
\text { learning }{ }^{1}\end{array}$ & & \\
\hline & $\begin{array}{l}\text { Beech Setting: } 4-5 \text { year-old boys and girls } \\
(n=46) \text { and their practitioners }(n=7) \text {. 'Open } \\
\text { framework' pedagogy }\end{array}$ & & \\
\hline & $\begin{array}{l}\text { Cherry Setting: } 4-5 \text { year-old boys and girls }(n= \\
60) \text { and their practitioners }(n=5) \text {. 'Open } \\
\text { framework' pedagogy }\end{array}$ & & \\
\hline 3 & $\begin{array}{l}\text { Children who had participated in Phase II and } \\
\text { their families (self-selected). Social class } A, A / B \\
\text { or } B^{2}\end{array}$ & $\begin{array}{c}\mathrm{N}=5 \text { children and } \\
\text { their families }\end{array}$ & $\begin{array}{l}\text { Interview conversations } \\
\text { Observations } \\
\text { Focus groups }\end{array}$ \\
\hline
\end{tabular}




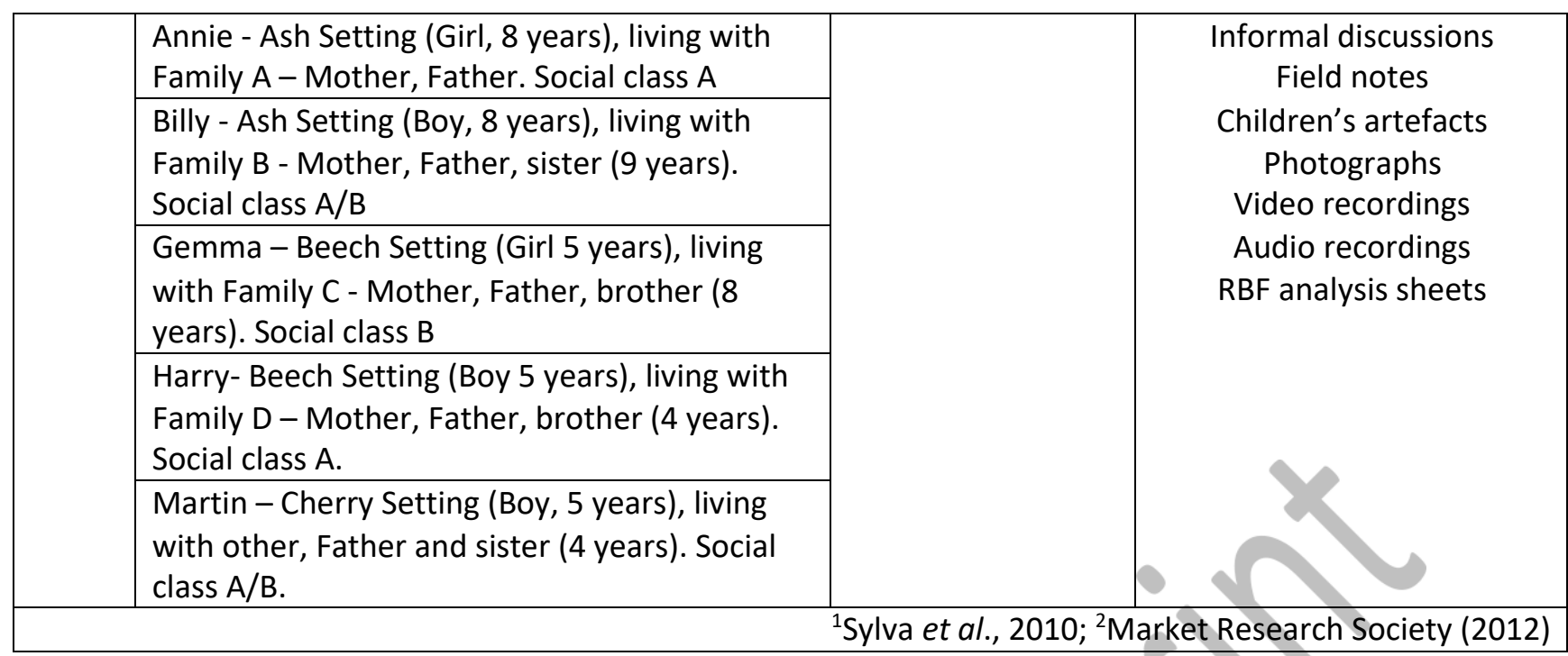

Members of the academy enjoy a 'unique position of privilege' (Farnum, 2014: 4) and their collective hegemony means that recognition of young children as researchers relies on the academy acknowledging that certain aspects of young children's activity may conform to its accepted definitions and protocols. Establishing these at the outset of the study was therefore important and was achieved empirically in Phase 1 and non-empirically through literature review (inter alia, Ayer, 1940; Bridges et al., 2009; Johnson-Laird and Byrne, 1991; Scruton, 2001).

Phase 2 data focused on young children's everyday activities in early childhood settings within three English primary schools and Phase 3 data were concerned with young children's everyday activities at home. The five children in Phase 3 attended Phase 2 settings and elected to participate at home as well as school.

Adopting multiple tools for data collection provided rigour and optimised participant engagement by valuing participants' contributions. For example, professional adult researchers' data defining research were captured in Phase 1 focus groups, semi-structured interviews and a nominal grouping exercise, securing the rigour that thick description and triangulation bring (Ryle, 1968; Patton, 2002), In Phases 2 and 3, artefacts that participating children offered included pictures, photographs, 
paintings and models constructed from recycled materials. Regarding these as authentic data supported interpretations of children's actions, meanings and thinking and valued their preferred ways of presenting these (Hardman, 1973; Lansdown, 2010).

To elicit trustworthy data democratically (Guba, 1981), participants, including children aged 4-8 years also engaged in an inductive, recursive process of analysis, meta-analysis and interpretation. The process was influenced by the four selected methodologies. For constructivist grounded theory, this included constant comparison, memo writing and varied coding models (Charmaz, 2006). Aspects of critical ethnography analysis included dialogic data generation, discovering system relations, reconstructive analysis and repeated thinking (Carspecken, 1996; Thomas, 1993). Child conferencing and listening were key analysis tools for the mosaic approach (Clark and Moss, 2011), while analytic statements common to case study proved valuable (Yin, 2012).

\section{Ethics}

Ethical considerations infused both form and function of YCAR which was conducted according to British Educational Research Association (BERA) $(2004 ; 2011)$ guidelines and the required institutional code and procedures. For example, participants' anonymity is protected by pseudonyms. Yet while YCAR was an exploration of democratic research, a tension existed between ethical protocols and ethical processes: the ethics committee requirement that the study should be fully planned from the beginning signalled limited possibilities for participants to contribute to the research design and limited reflexivity with participants throughout. These issues were resolved by seeking incremental ethical agreement, but it was cumbersome. Because of legal implications inherent in giving consent (Coyne, 2010), children assented to participation (Harcourt and Conroy, 2005); parental consent was sought prior to asking children to assent (BERA, 2011) although two parents withheld consent, denying their children the opportunity to decide (Murray, 2011). 


\section{Support structures for young children's research behaviours}

This section presents and discusses YCAR findings concerning support structures for young children's research behaviours.

Rather than providing a simple definition of research, the professional researchers who participated in Phase 1 identified 39 research behaviours, establishing four of these as the 'most important' in a nominal grouping exercise (Delbecq and VandeVen, 1971): exploration, finding a solution, conceptualisation and basing decisions on evidence. Phases 2 and 3 focused on the four important research behaviours to secure evidence for an argument that aspects of young children's everyday activity may be congruent with professional adult researchers' behaviours. There is consensus within the academy that the nature of research evidence is varied and may include, inter alia, observable data, personal accounts and philosophical argument (Bridges, Smeyers and Smith, 2009; Ayer, 1940; Scruton, 2001; Johnson-Laird and Byrne, 1991).

To contextualise empirical data collected in Phases 2 and 3 which revealed research behaviours in young children's everyday activities, a detailed review of extant literature was undertaken, featuring definitions of the four important research behaviours. Detailed aspects of the review are presented in other publications (Murray, 2012; 2013; 2016; 2017) but for this article, brief extracts are presented, defining the four most important research behaviours.

Exploration: Stebbins (2001) proposes that exploration in social sciences research is 'to study, examine, analyse (sic), or investigate...to become familiar with something by testing it or experimenting with it...to travel over or through a particular space for the purposes of discovery (and) to examine a thing or idea for (specific) diagnostic purposes' (p.2). 
Finding a Solution - or problem-solving - is engagement in high-order thinking (Keen, 2011).

Problem-solving combines hidden goals, strategies and evaluation

(DeLoache, Miller, and Pierroutsakos, 1998) and often involves deductive thinking (Johnson-Laird and Byrne, 1991).

Conceptualisation is regarded as '...a process of thinking about a problem situation through particular "concepts"' (Metcalfe, 2007: 149); concepts are defined as 'clearly specified ideas deriving from a particular model' (Silverman, 2006: 400). Those concepts may be $a$ priori if they are pure reasoning or a posteriori if they correlate sensory experience with mental activity to derive justified knowledge (Hume, 1748; Kant, 1787; Scruton, 2001).

Basing Decisions on Evidence: The nature of evidence is varied (Bridges et al., 2009). Decision making comprises 'acts or options among which one must choose; the possible outcomes or consequences of these acts and the contingencies or conditional probabilities that relate outcomes to acts' (Tversky and Kahneman 1981:453). Basing decisions on evidence is, then, the application of recognised information, with reasoning, to identify a rationale for choice.

What supported young children to participate in research?

Across 238 setting and 154 home analyses of young children's everyday activities, 1601 incidences emerged from the YCAR data of young children engaging in the four important research behaviours (Table 2).

Table 2: Incidences of young children's engagements in research behaviours

\begin{tabular}{|l|l|l|l|}
\hline Research Behaviour & $\begin{array}{l}n=\text { incidences of } \\
\text { research behaviour }\end{array}$ & $\begin{array}{l}n=\text { analyses of } \\
\text { setting data }\end{array}$ & $\begin{array}{l}n=\text { analyses of } \\
\text { home data }\end{array}$ \\
\hline Explore & 636 & 88 & 53 \\
\hline Find a Solution & 305 & 56 & 36 \\
\hline Conceptualise & 268 & 44 & 31 \\
\hline Base Decisions on Evidence & 392 & 50 & 34 \\
\hline
\end{tabular}


From these data, 80 categories emerged and were grouped into nine factors (Figure 1). These categories and factors supported young children's engagements in the four important research behaviours. They are ways that we can know children know and ways we can know how children come to know, so they are termed epistemological categories and epistemological factors. Some categories inhibited young children's engagement in research behaviours so are labelled epistemological barriers. The epistemological categories and epistemological factors form 'building blocks' that support research behaviours young children engage in during their everyday activities (Murray, 2015a; 2016; 2017).

Figure 1: Nine Epistemological Factors: Building blocks for research behaviours

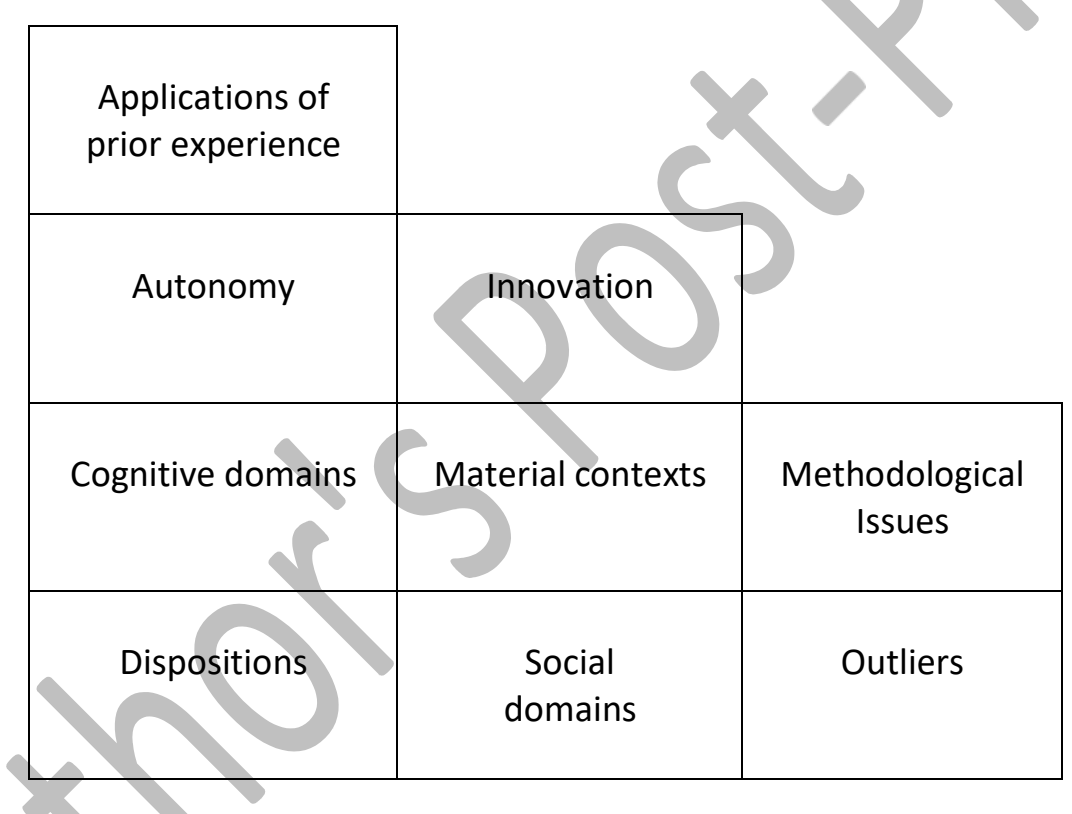

Seven of the epistemological factors that emerged from the YCAR study are now presented, and discussed critically through a series of vignettes, each of which provides one example of an epistemological category within an epistemological factor. Two factors are not exemplified and discussed here: 'Methodological issues' only occurred because the YCAR study was conducted, whilst 'Outliers' was less distinctive than other epistemological factors. 
Application of prior experience resonates with a key philosophical idea that informs the academy's work: a posteriori reasoning, or sensory experience combined with mental activity to make a judgement (Scruton, 2001). The epistemological factor 'Applications of prior experience' features thirteen epistemological categories spread across all four important research behaviours and one epistemological barrier to 'Finding a Solution' (Figure 2). One of the epistemological categories within this factor is 'Applies a mental model', an action that supported young children in the YCAR study to engage in the research behaviour 'Basing decisions on evidence'.

Figure 2: Building Blocks for Applications of Prior Experience

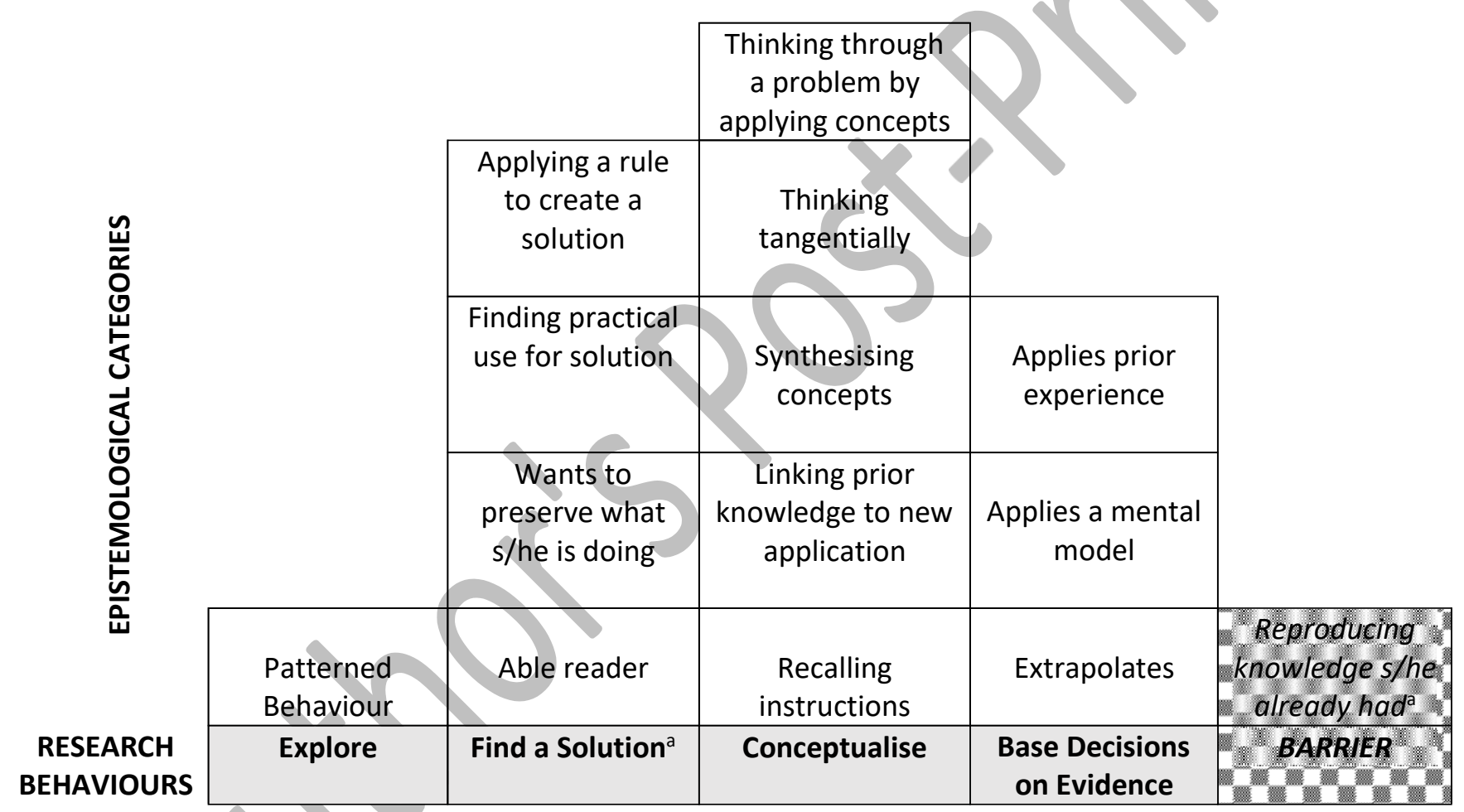

Note: Superscript ${ }^{a}$ indicates the barrier links to the research behaviour 'Find a Solution'.

Craik (1943) describes mental modeling as:

'(1) "Translation" of external processes into words, numbers or other symbols;

(2) Arrival at other symbols through a process of "reasoning", deduction, inference, etc.

(3) "Retranslation" of these symbols into external processes' (p.50). 
In this vignette, Martin (aged 5) was playing with Jack, Adel and Fergus (all aged 5) and Nora (aged 4) during a free-flow session in Cherry Setting. The children found a measuring stick and Jack measured Adel.

Martin: 'How tall are you?'

Jack: 'Yeah but you're right up here and I am too tall.'

Adel: 'You are taller than Fergus.'

Adel 'I am taller than Nora-look!'

Here, the children revisited their prior experience of a measuring stick used to measure height, alongside the word 'tall' and they did so while comparing their heights. They exemplified mental modelling (Craik, 1943): they translated the external process of measuring that they had previously experienced to measure each other with the measuring stick. They used the word 'tall' while measuring a child against the stick. They then retranslated this to 'taller' when comparing each other's heights and they reasoned that some children were taller than others.

Autonomy

YCAR data often revealed children's agency (Dahlberg and Lenz Taguchi, 1994).

Autonomy is another epistemological factor that emerged from YCAR: it features eight epistemological categories, across all four research behaviours (Figure 3). Within 'Autonomy', one of the epistemological categories is 'Develops own agenda', an action that supported young children participating in YCAR to engage in the research behaviour 'Exploration'. Castle (2004) recognises that autonomy has different meanings: it may, for example, mean regulating one's own behaviour (DeVries and Zan, 1994) or freedom from control (Freire, 1972). Opportunities for young children to act autonomously are considered valuable because they help young children to 'feel more in control of their own lives and give them self-respect' (Dowling, 2010: 59). 


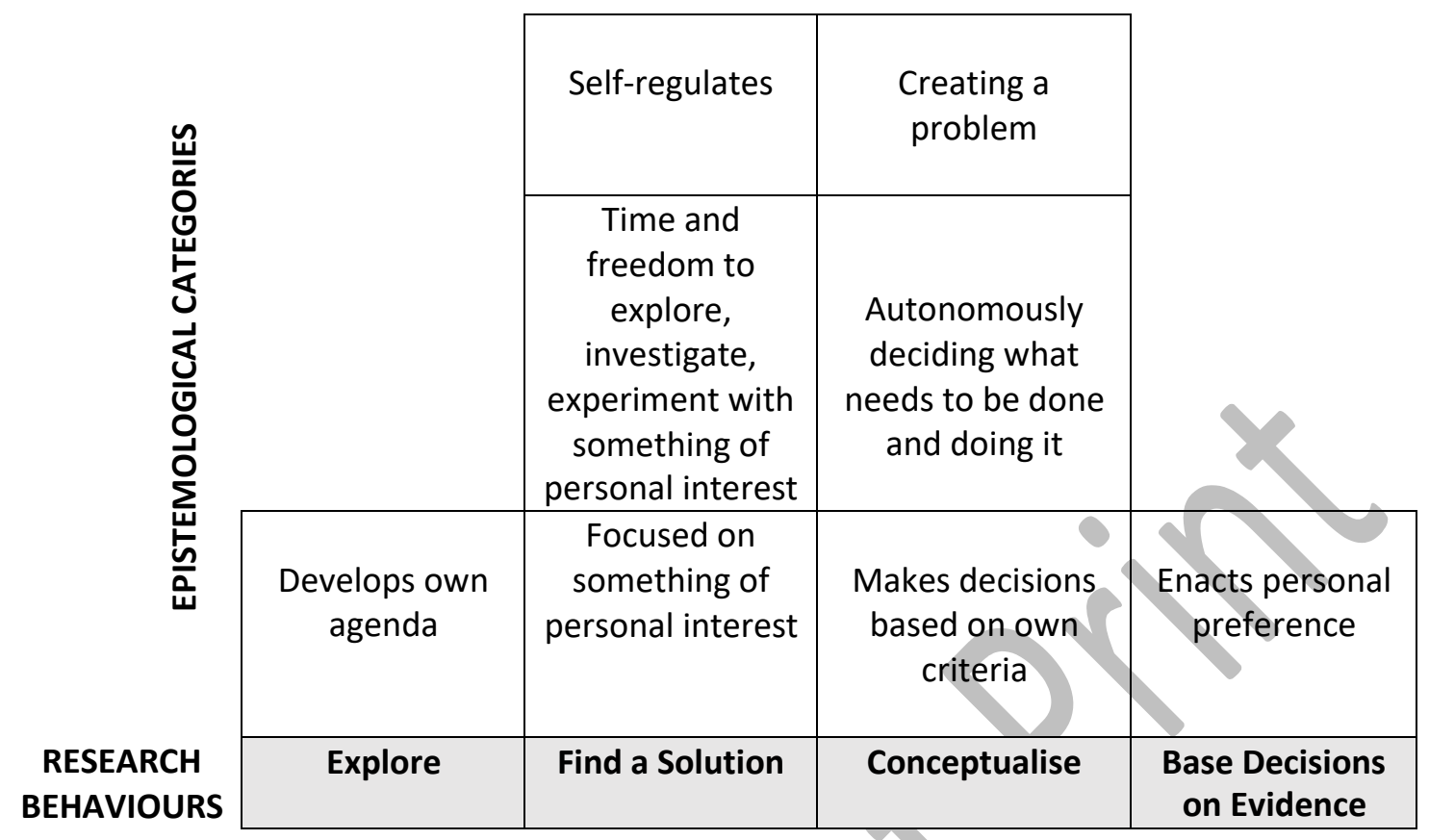

At home one day, Gemma (aged 5) decided to make jewellery on her own and wrap it up. She had no prompts and had to explore how to use only materials that were available to create jewellery. She told her mother what she was doing and later gave her a bracelet she had made. Here, Gemma had freedom from control (Freire, 1972; Dowling, 2010) and regulated her own behaviour (DeVries and Zan, 1994), demonstrating autonomy.

Cognitive domains

The epistemological factor 'Cognitive domains' contains twelve epistemological categories that support three research behaviours - 'Exploration', 'Conceptualisation' and 'Bases Decisions on Evidence' (Figure 4). One of these epistemological categories is 'Using imagination' which supported young children's engagements in the research behaviour 'Conceptualisation'. Newson and Newson (1979:12) describe imagination as 'extensive and complex'; Kant (1787) regarded imagination as 'the very condition of possibility for all knowledge and experience' (Norris, 2000: 384). Imagination is a mental picture of something that the senses cannot discern (Perdue, 2003). During an interview 
conversation at home, Billy (aged 8) described a tank and toy figure he had pictured in his mind then made from a cardboard box and craft materials:

Billy: I made a Star Wars figure

Researcher: And what's this bit for then - poking out of the top?

Billy: This bit gives the person who's controlling the tank here his seat. He's not allowed to sit anywhere else - he can't see so I made this here so he can see.

Figure 4: Building Blocks for Cognitive Domains

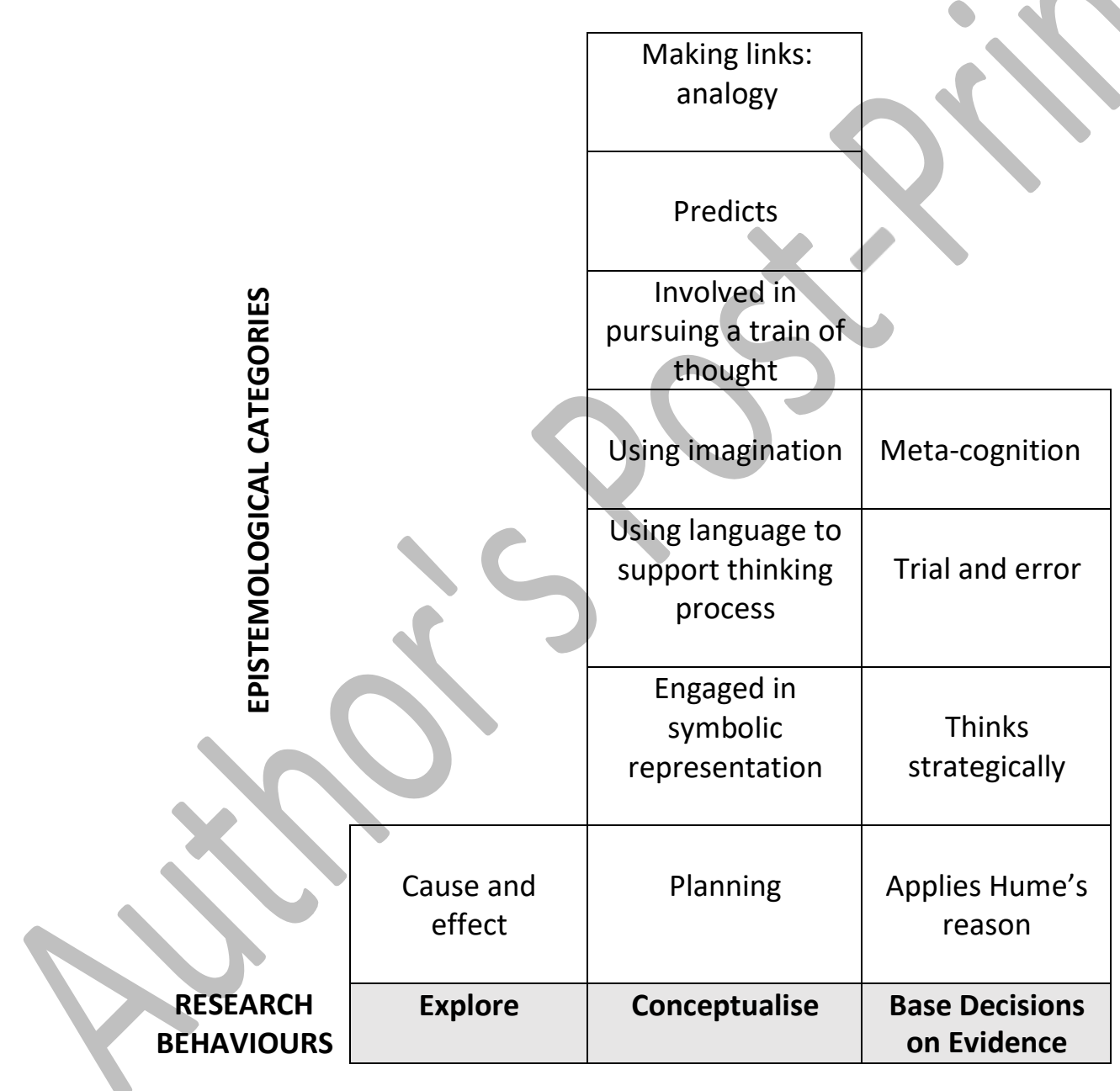

Here, Billy revealed that he had created a mental picture of something that his senses could not yet discern because he had not yet made it (Perdue, 2003). However, his mental picture was a 'clearly specified idea deriving from a particular model' - Silverman's definition of conceptualisation (2006: 400) - because he had previously seen a Star Wars figure and a tank, either in reality or as an image. Billy had then reified his mental picture: he made the Star Wars figure and the tank. 
Dispositions

Katz (1993) defines a disposition as '...a pattern of behavior (sic) exhibited frequently and in the absence of coercion, and constituting a habit of mind under some conscious and voluntary control, and that is intentional and oriented to broad goals'. 'Dispositions' emerged as an epistemological factor, with six epistemological categories across two research behaviours 'Exploration' and 'Find a Solution' and four epistemological barriers to the research behaviour 'Find a Solution' (Figure 5).

Figure 5: Building Blocks for Dispositions

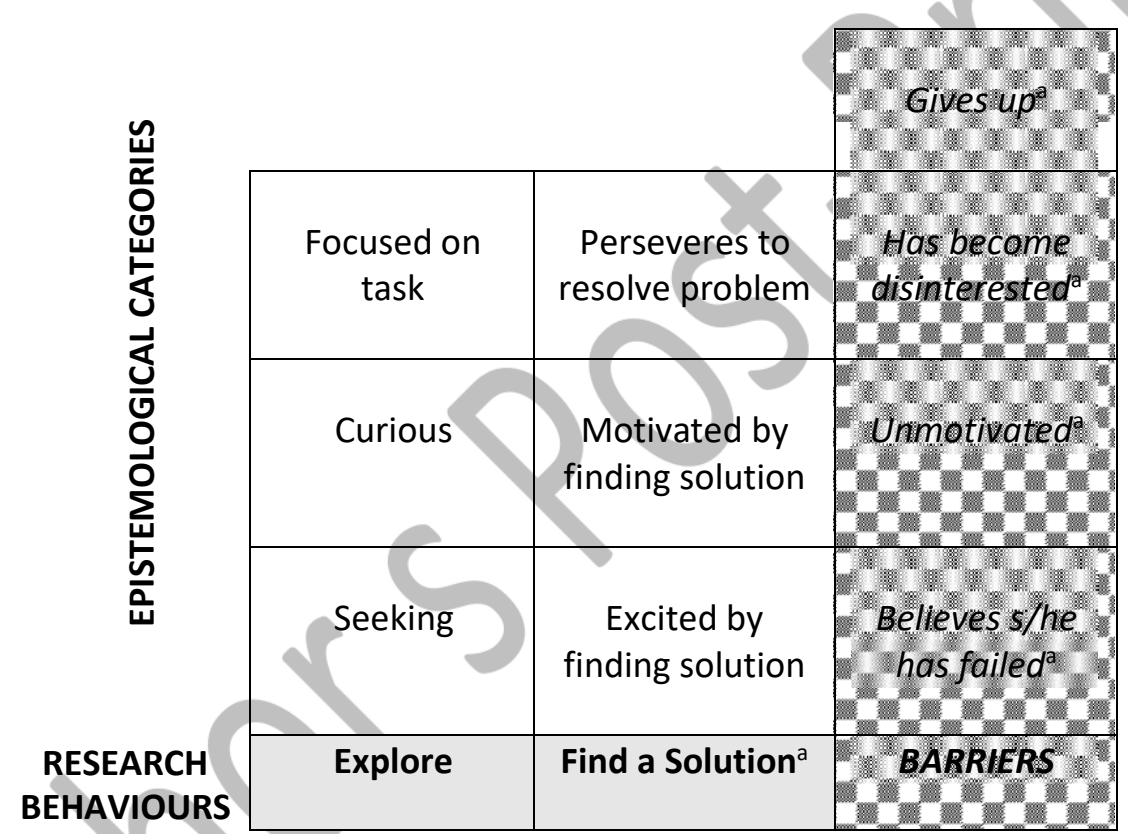

Note: Superscript ${ }^{a}$ indicates the barrier links to the research behaviour 'Find a Solution'.

Being 'Curious' supported YCAR children to engage in the research behaviour 'Exploration'. This finding endorses work undertaken by Laevers (2000:21) who confirms 'curiosity' as a disposition, describing it as 'the exploratory drive'. Nora (aged 5) exemplified this finding in Cherry Setting. She was sitting in a circle on the carpet with her class while the teacher was reading the section of the children's story 'We're Going on a Bear Hunt' (Rosen, 1989) when a family splashes through the river to find the bear. The teacher had prepared a bowl of water because she wanted the children to feel the water as a stimulus for thinking of adjectives to describe water after the story. While Nora 
listened to the story, she chose to dip her right-hand fingers into the bowl of water, wiggled them in the water, smelled her fingers and touched her lips with her wet fingers.

Nora engaged in a repeated sequence of behaviour: she submitted the water to a series of tests, using different senses. Aligning with Katz's definition of a disposition (1993), Nora was not coerced, but intended to do this: she chose to put her hand into the water while listening to the story, to explore the properties of the water at first hand. Nora repeatedly demonstrated 'epistemic curiosity' (Berlyne, 1954: 180), while fulfilling Chak's dual criteria for curiosity (2007:42): by choosing to dip her fingers in the water, Nora demonstrated 'motivational force' and her actions enabled her to sample the water through her senses, providing a 'behavioural manifestation in the form of exploration'. Nora's behaviour enabled her to investigate the water and test its properties, aligning with Stebbins' definition for exploratory research (2001).

Innovation

'Innovation' - an epistemological factor - is the act of doing or creating something in a new way (Costello and Prohaska, 2013); this action should be applied in a way that is beneficial for innovation to be of value (Costello and Prohaska, 2013; Department for Business, Innovation and Skills (DBIS), 2012). There are eight epistemological categories within Innovation supporting the research behaviours 'Exploration', 'Find a Solution' and 'Conceptualisation' (Figure 6).

'Devises a practical method to create a solution' is an epistemological category supporting the research behaviour 'Find a Solution'. Bridges (2003) links problem-solving and pragmatism, a philosophy strand deriving from '...praxis, an activity that recognises that we are always part of the world we study' (Siraj-Blatchford, 1994: 18). Praxis was the Ancient Greeks' term for 'practical knowledge', requiring 'personal wisdom and understanding, not expertise' (Griffiths and MacLeod, 2008:128-9). 


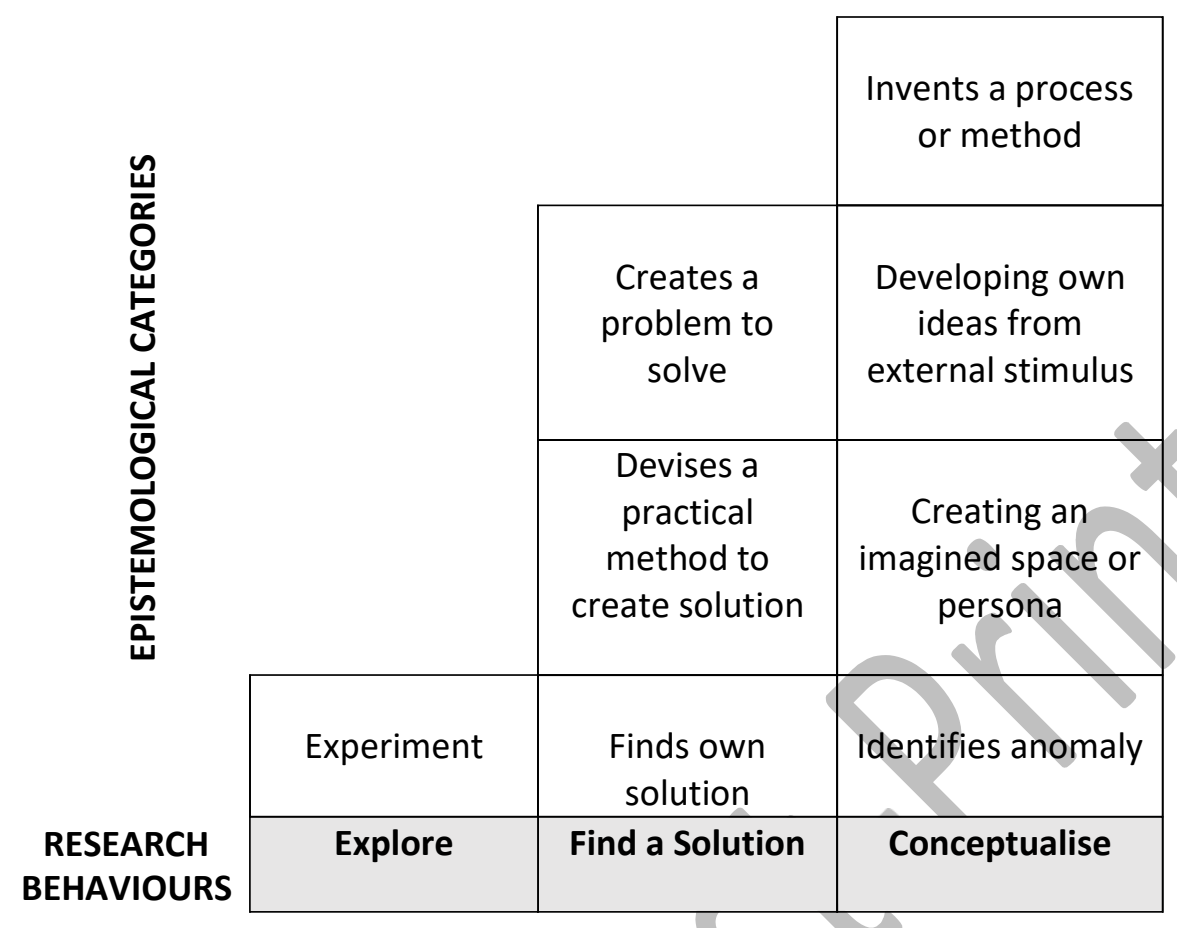

One day, during free flow play in Cherry Setting, Querida picked up a butterfly she had made from pipe cleaners and paper and said: 'It's broken'. Querida took the butterfly to the making table and said: 'I'm going to mend my butterfly'. Using a piece of pipe cleaner, she attempted to fix her butterfly but it did not work. She said: 'I need a bit longer pipe cleaner'. She found a longer pipe cleaner, stuck it on then held up her mended butterfly. Querida devised a practical method to create a solution; having tried a short pipe cleaner and finding it did not solve her problem, Querida used a longer pipe cleaner which worked. This was the act of doing something in a new way that was beneficial: innovation (Costello and Prohaska, 2013).

\section{Material contexts}

The epistemological factor 'Material Contexts' features seven epistemological categories that influenced young children's engagements in all four of the YCAR research behaviours (Figure 7). 'Senses provide evidence for action' was an epistemological category that supported children to engage in the research behaviour 'Base Decisions on Evidence'. It aligns with the aspect of Hume's 
'principle of verification' (1748:123) stating that 'learned work' should feature '...reasoning concerning matter of fact and existence' (Thomas, 2007).

Figure 7: Building Blocks for Material Contexts

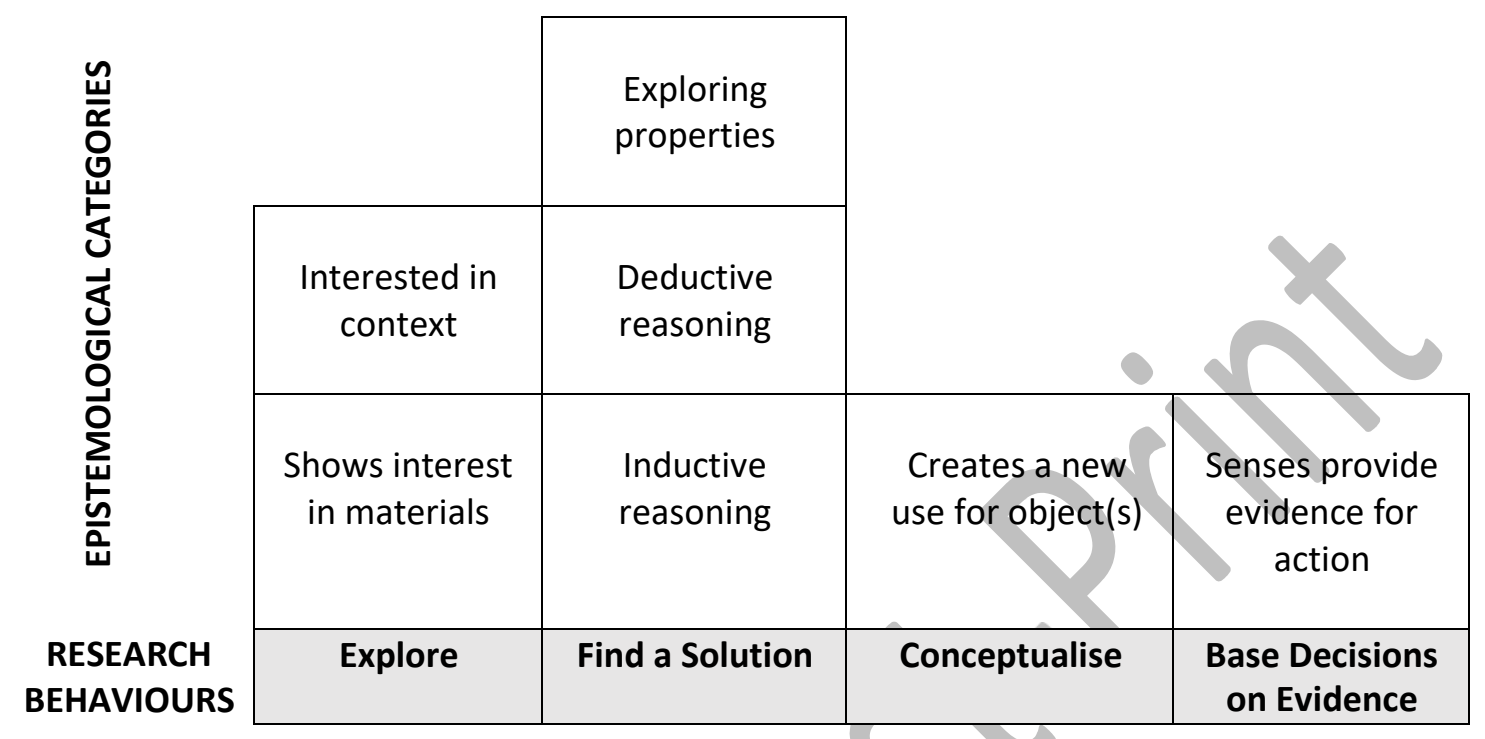

At the start of an art lesson in Ash Setting, the teacher showed the class of 7 and 8-year-old children how to make some African designs before setting them a task to create African designs with the learning objective: 'To be able to understand features of African designs'. The children were required to place a wooden frame $10 \mathrm{~cm} \times 10 \mathrm{~cm}$ on a piece of fabric and copy what was captured in the frame on a piece of paper. Edward (aged 8) arrived just after the teacher's exposition and joined three of his peers at a table. He looked at what they were doing, picked up a frame, fabric and paper and began to copy them, drawing the pattern. He looked up at what the other children were doing again, then refocused on his own work, looked closely at the pattern on the fabric, then drew the pattern four times.

In this vignette, Edward used his sense of sight to identify what his peers were doing, enabling him to work out what he was required to do in the art lesson; he reasoned based on '...matter of fact and existence', which is a key characteristic of Hume's principle of verification (1748:123; Thomas, 2007). 
Edward engaged in Basing decisions on evidence: he combined information with reasoning to identify a rationale for choosing how to proceed.

\section{Social domains}

The epistemological factor 'Social domains' comprises ten epistemological categories across all four research behaviours as well as six epistemological barriers to the research behaviour Find a Solution (Figure 8).

Figure 8: Building Blocks for Social Domains

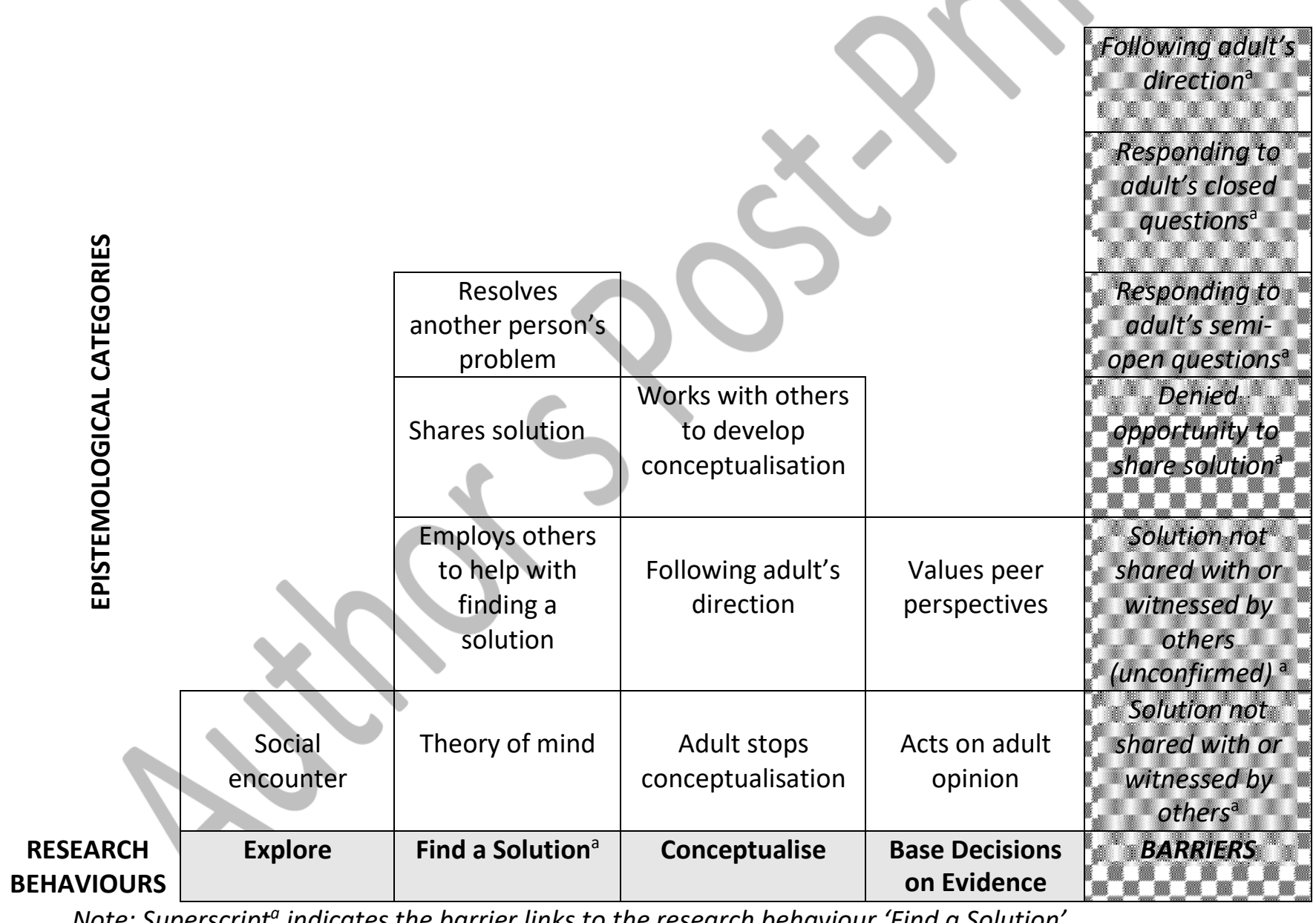

Note: Superscript ${ }^{a}$ indicates the barrier links to the research behaviour 'Find a Solution'.

In the YCAR study, 'Theory of Mind' (TOM) supported young children to engage in the research behaviour 'Find a solution'. Meltzoff (1995) describes TOM as '...the understanding of others as psychological beings having mental states such as beliefs, desires, emotions and intentions' (p.838). 
TOM is important for understanding others' behaviours: 'our ability to make sense of agents' actions rests in large part on our ability to understand the mental states that underlie their actions' (Song, Onishi, Baillargeon and Fisher, 2008:295).

One day in Cherry Setting, the teacher introduced the 'Cross the River' game to the children. She organised them into two long lines facing each other, showed them some cards with words on and said: 'We're going to match our caption. When you've got a match, go and sit with your match on the carpet.' The children took turns to read their card and match it to a card held by another child in the other line.

When it was his turn, Martin (aged 5) held his card upside down so the children on the other side could see it. He read his card upside down - 'pack a pen in a bag' - then his partner in the other line also read it aloud so could came to sit with Martin. Martin demonstrated TOM (Meltzoff, 1995): his action indicated that he understood his partner needed to be able to read the card: he presented it the right way up for his partner, though upside down for himself. He found a solution by helping his partner.

\section{Discussion and Implications}

The findings presented above exemplify, elucidate and critique the support structures that encouraged young children in the YCAR study to engage in research behaviour: the epistemological categories and epistemological factors. In the Young Children As Researchers study, epistemological factors included Applications of prior experience, Autonomy, Cognitive domains, Dispositions, Innovation, Material contexts and Social domains. Epistemological categories and epistemological factors are also ways that we can know that young children build knowledge. 
The epistemological factors and their constituent epistemological categories are helpful because they provide a warrant for recognising children's everyday activities as research behaviours that are congruent with research on the academy's terms. In the YCAR study, professional adult researchers identified the academy's research behaviours, then evidence was captured indicating that young children engaged in those research behaviours as part of their everyday activity, providing a deductive argument that those young children engaged in research (Johnson-Laird and Byrne, 1991). That warrant is based on evidence and deductive reasoning which are key terms on which the academy operates (Bridges et al., 2009; Johnson-Laird and Byrne, 1991). The warrant provides justification for young children's rights to research in matters that affect them to be respected and upheld by the academy on equal terms with those of professional adult researchers.

Nevertheless, this claim is predicated on the ability of adults to recognise aspects of young children's everyday activity as research behaviour. The YCAR epistemological categories and epistemological factors are particularly valuable because they also provide a lens through which we can view how children research in different contexts using different modalities; they enable us to recognise and value young children's actions which are congruent with research behaviours the academy members identified in Phase I of the YCAR study. Additionally, the epistemological categories and epistemological factors may prove a useful tool for helping early childhood practitioners and parents to recognise how young children learn by building knowledge and understanding in their everyday activities.

The inclusion of this article in a peer-reviewed journal is an opportunity to present to the academy the warrant that has emerged from the YCAR study. It carries a message to that 'rarefied world' (Redmond, 2008:9) that young children's rights to research concerning matters affecting them can be regarded on equal terms with those of adult researchers. Wider implications of this recognition are that such research could then be used to inform early childhood education and care policy and 
practice in a deeply grounded manner that values young children as competent, 'sophisticated' thinkers who have expertise concerning their own lives (James and James, 2008; Langsted, 1994; Papert, 1980: 132). In terms of social justice, such recognition has the potential to secure young children's rights to research (Appadurai, 2006; OHCHR, 1989; 2005).

\section{Conclusion}

The academy is in a 'unique position of privilege' (Farnum, 2014: 4) and its hegemony means that recognition of young children as researchers is reliant on academy members acknowledging that certain aspects of young children's activity may conform to its accepted definitions and protocols. Yet young children have tended to be marginalised by the academy and disregarded as researchers in matters affecting them: adults find it difficult to understand young children's actions, meanings and thoughts (Hardman, 1973; Redmond, 2008), so equating young children's actions, meanings and thoughts with those of professional adult researchers whose work is privileged by the academy has rarely been achieved.

The YCAR study captured examples of young children's 'epistemic interest and inquiry' in their everyday activity (Isaacs, 1944) and revealed their congruence with professional adult researchers' behaviours, to establish a warrant for young children to be recognised as researchers on the academy's terms, particularly concerning matters affecting them. This is a matter of social justice.

The nine epistemological factors and 80 epistemological categories that emerged from the YCAR study provide evidence to justify the warrant that young children can be recognised as researchers on the academy's terms. Epistemological factors and epistemological categories are support structures that young children adopt naturally to enable them to engage in the research behaviours that professional researchers regard as most important: exploration, finding solutions, conceptualisation and basing decisions on evidence. Epistemological factors and epistemological 
categories also act as lenses that enable adults to view how children research in ways that are congruent with behaviours the academy recognises as research. Additionally, the YCAR epistemological categories and epistemological factors may prove useful for helping early childhood practitioners and parents to recognise how young children learn by building knowledge and understanding in their everyday activities.

These findings indicate that the time has come for the academy to recognise young children as researchers in matters concerning their own lives and to include their research within the academy's remit. Such recognition would afford young children rights to research and would reposition them away from the margins of research to an intrinsic position in research that concerns matters affecting them.

\section{Acknowledgements}

The author extends sincere thanks to Professor Richard Rose, Professor Philip Gammage and her fellow researchers on the Young Children As Researchers project: the children, their families and their practitioners, as well as professional researchers from within the academy.

\section{References}

Ackerman, E. (2001) Piaget's constructivism, Papert's constructionism: What's the difference? Accessed: 15.2.17. http://learning.media.mit.edu/content/publications/EA.Piaget\%20 \%20Papert.pdf

Alderson, P. 2001. "Research by Children" International Journal of Social Research Methodology 4 (2): 139-153.

Appadurai, A. 2006. "The right to research" Globalisation, Societies and Education 4 (2): 167-177. doi 10.1080/14767720600750696

Ayer, A.J. 1940. The Foundations of Empirical Knowledge. London: MacMillan and Co., Ltd.

Berlyne, D.E. 1954. "A Theory of Human Curiosity." British Journal of Psychology 54 (3),180-191.

Bridges, D. 1998. "Research for Sale: moral market or moral maze?" British Educational Research Journal, 24 (5): 593-607. 
Bridges, D. 2003. Fiction written under Oath. Dordrecht: Kluwer Academic Publishers.

Bridges, D., P. Smeyers and R. Smith, eds. 2009. Evidence-based education policy. Chichester: Wiley Blackwell.

British Educational Research Association. 2004; 2011. Ethical Guidelines for Educational Research. London: British Educational Research Association.

Brownlie, J., S. Anderson and R. Ormston. 2006. Children as researchers. Edinburgh: Scottish Executive Education Department.

Cagliari, P., Castagnetti, M., Giudici, C., Rinaldi, C., Vecchi, V. and Moss, P. (Eds.) 2016. Loris

Malaguzzi and the Schools of Reggio Emilia: A selection of his writings and speeches, 1945-1993.

Abingdon: Routledge.

Carspecken, P. 1996. Critical ethnography in educational research. London: Routledge.

Castle, K. 2004. "The meaning of autonomy in early childhood teacher education." Journal of Early Childhood Teacher Education 25 (1): 3-10.

Chak, A. 2007. "Teachers' and parents' conceptions of children's curiosity and exploration."International Journal of Early Years Education 15 (2): 141-159.

Charmaz, K. 2006. Constructing grounded theory. London: Sage.

Clark, A. and Moss, P. (2011) Listening to young children. London: National Children's Bureau.

Costello, T. and B. Prohaska. 2013. “Innovation." IT Pro 15 (3): 62-64.

Coyne, I. 2010. "Research with children and young people: The issue of parental (proxy) consent." Children and Society 24 (3): 227-237.

Craik, K. 1943. The nature of explanation. Cambridge: Cambridge University Press.

Dahlberg, G. and Lenz Taguchi, H. 1994. Förskola och skola och om visionen om en mötesplats [Preschool and school and the vision of a meeting-place]. Stockholm: HLS Förlag.

Delbecq, A.L. and VandeVen, A.H. 1971. "A Group Process Model for Problemldentification and Program Planning." Journal of Applied Behavioral Science VII, July/August, 1971: 466 -491.

DeLoache, J.S., K.F. Miller, and S.L. Pierroutsakos. 1998. "Reasoning and problem solving." In D. Kuhn and R. Siegler (Eds.) Handbook of child psychology, 5th Edition, Vol 2: Cognition, perception and Language. Pp. 801-850. New York: Wiley.

Department for Business, Innovation and Skills 2012. "Innovation". Accessed 30.9.16. http://www.bis.gov.uk/innovation

DeVries, R.and B. Zan 1994. Moral classrooms, moral children. New York: Teachers' College Press.

Dowling, M. 2010. Young Children's Personal, Social and Emotional Development. London: Sage. 
Farnum, R. (2014) Contesting or Creating Hegemony? A critique of the London Water Research Group considering academic hegemony and traps in social justice research. Concept Paper prepared for HH7. Accessed 5.11.16 at https://www.uea.ac.uk/documents/40159/5624523/Contesting+or+Creating+Hegemony++LWRG+Critique.pdf/e94acbb0-f28c-4b84-8819-501d91f1433a

Fernyhough, C. 2010. The baby in the mirror: A child's world from birth to three. London: Granta Publications.

Fielding, M. 2001. "Students as Radical Agents of Change." Journal of Educational Change 2 (2): 123141.

Freire, P. 1972. Pedagogy of the oppressed. Harmondsworth: Penguin.

Frost, N., S.-M. Nolas, B. Brooks-Gordon, C. Esin, A. Holt, L. Mehdizadeh, L. and P. Shinebourne, 2010. "Pluralism in qualitative research: The impact of different researchers and qualitative approaches on the analysis of qualitative data." Qualitative Research, 10 (4): 441-460.

Griffiths, M. and G. MacLeod. 2009. "Personal Narratives and Policy: Never the Twain?" Journal of Philosophy of Education, 42 (S1): 121-143.

Guba, E.G. 1981. Criteria for assessing the trustworthiness of naturalistic inquiries. Educational Communication and Technology Journal, 29: 75-91.

Harcourt, D. and Conroy, H. 2005. "Informed Assent: Ethics and Processes when Researching with Young Children." Early Child Development and Care, 175 (6): 567-577. doi

org/10.1080/03004430500131353

Hardman, C. 1973. "Can there be an Anthropology of Children?" Journal of the Anthropology Society of Oxford, 4 (1): 85-99.

Hatch, J.A. 2007. Back to Modernity? Early Childhood Qualitative Research in the $21^{\text {st }}$ Century? In Early Childhood Qualitative Research, edited by J.A. Hatch, 7-24. (2007) London: Routledge.

Hedges, H. 2014. "Young children's 'working theories': Building and connecting understandings." Journal of Early Childhood Research, 12 (1): 35-49.

Hughes, P. 2010. "Paradigms, Methods and Knowledge", in Doing Early Childhood Research, 2e, edited by G. MacNaughton, S.A. Rolfe and I. Siraj-Blatchford, 35-62. Maidenhead: Open University Press / McGraw-Hill.

Hume, D. 1748. "An Enquiry Concerning Human Understanding." In David Hume: An Enquiry Concerning Human Understanding, edited by T. Beauchamp, ed. (2000), 5-123. Oxford: Oxford University Press.

Isaacs, N. 1944. Children's 'why' questions. In Intellectual Growth in Young Children, edited by S. Isaacs, 291-354. London: Routledge.

James, A. and James, A. 2008. Key concepts in childhood studies. London: Sage.

Johnson-Laird, P.N. and R.M.J. Byrne 1991. Deduction. Hillsdale: Lawrence Erlbaum Associates. 
Kant, I. 1787. The Critique of Pure Reason. Prepared in e-text by C. Aldarondo 2003. Project Gutenberg. Accessed 16.9.16. http://www.gutenberg.org/dirs/etext03/cprrn10.txt

Katz, L.G. 1993. Dispositions: Definitions and implications for early childhood practices. Catalogue No. 211 Perspectives from ERIC/EECE: Monograph series no. 4. Accessed 16.9.16. http://ecap.crc.illinois.edu/eecearchive/books/disposit/index.html

Keen, R. 2011. "The development of problem solving in young children: a criticalcognitive skill." Annual Review of Psychology, 62: 1-21.

Kellett, M. 2005. How to Develop Children as Researchers. London, UK: Sage.

Laevers, L. 2000. "Forward to Basics! Deep-level-learning and the experiential approach." Early Years: An International Journal of Research and Development, 20 (2): 20-29.

Langsted, O. 1994. "Looking at Quality from the Child's Perspective." In Valuing Quality in Early Childhood Services: New approaches to defining quality, edited by P. Moss and A. Pence, 28-42. London: Paul Chapman.

Lansdown, G. 2010. The Realisation of Children's Participation Rights, in A Handbook of Children and Young People's Participation, edited by B. Percy-Smith. and N. Thomas, 11-23. London: Routledge.

Lees, L. 1999. "Critical geography and the opening up of the academy: lessons from 'real life' attempts." Area, 31 (4): 377-383. doi: 10.1111/j.1475-4762.1999.tb00104.x

Market Research Society (MRS) 2012. "Occupation Groupings." London: Market Research Society. Accessed on 30.9.16 https://www.mrs.org.uk/intelligence/occupational groupings

Meltzoff, A.N. 1995. Understanding the intentions of others: Re-Enactment of intended acts by $18-$ month-old children. Developmental Psychology, 31 (5): 838-850.

Metcalfe, M. 2007. "Problem Conceptualisation Using Idea Networks." Systematic Practice and Action Research, 20 (2): 141-150.

Murray, J. 2011. "Knock, Knock! Who's There? Gaining access to young children as researchers: a critical review" Educate 11 (1): 91-109.

Murray, J. 2012. "Young Children's Explorations: Young children's research?" Early Child Development and Care, 182 (9): 1209-1225.

Murray, J. 2013. "Young children's research behaviour?" Children aged 4-8 years finding solutions at home and at school. Early Child Development and Care, 183 (8): 1147-1165.

Murray, J. 2014. Researching Young Children's Worlds. In An Introduction to Early Childhood, edited by T. Waller and G. Davis, 325-345. London: Sage.

Murray, J. 2015a. Young Children as Researchers in Play. In The Excellence of Play, 4e, edited by J. Moyles, 106-124. Maidenhead: McGraw-Hill Education.

Murray, J. 2015b. Can Young Children be Researchers? In Children and Young People's Participation in Policy, Practice and Research, edited by H. McLaughlin, 48-63. London: National Children's Bureau. 
Murray, J. 2016. "Young children are researchers: Children aged 4-8 years engage in important research behaviour when they base decisions on evidence. European Early Childhood Education Research Journal 24 (5): 705-720. DOI: http://dx.doi.org/10.1080/1350293X.2016.1213565

Murray, J. 2017 (forthcoming). Building knowledge in early childhood education: young children are researchers. Abingdon: Routledge.

Newson, J. and Newson, E. 1979. Toys and playthings. New York: Pantheon Books.

Norris, C. 2000. "McDowell on Kant: Redrawing the bounds of sense." Metaphilosophy. 31 (4): 382411.

Office of the High Commissioner for Human Rights (OHCHR). 1989. "The United Nations Convention on the Rights of the Child." Accessed 30.9.16.

http://www.ohchr.org/en/professionalinterest/pages/crc.aspx

Office of the High Commissioner on Human Rights (OHCHR) 2005. Convention on the Rights of the Child: General Comment No 7. Implementing child rights in early childhood. Geneva: United Nations.

O'Kane, C. 2008. The development of participatory techniques. In Research with children, edited by P. Christensen, P. and A. James, 125-155. London: Routledge.

Papert, S. 1980. Mindstorms. children, computers and powerful ideas. New York: Basic books.

Patton, M. 2002. Qualitative Research and Evaluative Methods, 3e. Thousand Oaks, CA: Sage Publications.

Perdue, K. 2003. Theories of Media: Imagination. Accessed: 16.9.16 http://csmt.uchicago.edu/glossary2004/imagination.htm

Redmond, G. 2008. Children's Perspectives on Economic Adversity: A review of the literature. Innocenti Discussion Paper No. IDP 2008-01. Florence: UNICEF Innocenti Research Centre.

Rosen, M. 1989. We're going on a bear hunt. London: Walker Books Ltd.

Ryle, G. 1968. The Thinking of Thoughts: What is 'Le Penseur' doing? 'University Lectures', No.18. Saskatchewan: The University of Saskatchewan. Accessed: 5.11.16

http://lucy.ukc.ac.uk/CSACSIA/Vol14/Papers/ryle 1.html

Scruton, R. 2001. Kant. Oxford: Oxford University Press.

Sen, A. K. 1993. "Capability and Well-Being." In The Quality of Life, edited by M. Nussbaum and A. Sen, 30-53. Oxford: Oxford University Press.

Siraj-Blatchford, I. 1994. Praxis makes perfect: Critical educational research for social justice. Ticknall: Education Now.

Silverman, D. 2006. Interpreting Qualitative Data. London: Sage. 
Song, H.-J., K.H. Onishi, R. Baillargeon and C. Fisher. 2008. "Can an agent's false belief be corrected by an appropriate communication? Psychological reasoning in 18-month-old infants" Cognition, 109: 295-315.

Stebbins, R.A. 2001. Exploratory research in the social sciences. Thousand Oaks, CA: Sage.

Sylva, K., E. Melhuish, P. Sammons, I. Siraj-Blatchford and B. Taggart, eds. 2010. Early Childhood Matters: Evidence from the Effective Pre-school and Primary Education Project. London: Routledge.

Thomas, G. 2007. Education and theory: Strangers in paradigms. Maidenhead: Open University Press / McGraw-Hill.

Thomas, J. 1993. Doing Critical Ethnography. Newbury Park, CA: Sage.

Tversky, A. and D. Kahneman. 1981. The framing of decisions and the psychology of choice. Science 211 (4481): 453-458.

Warren, L. and Boxall, K. 2009. "Service Users In and Out of the Academy: Collusion in Exclusion?" Social Work Education: The International Journal, 28 (3): 281-297.

Woodhead, M. and Faulkner, D. 2008. Subjects, objects or participants: Dilemmas of psychological research with children. In Researching with Children, edited by P. Christensen and A. James, 10-39. London: Routledge.

Yin, R.K. 2012. Applications of Case Study Research. London: Sage. 